\title{
OPTIMATION OF ETHANOL CONCENTRATION IN EXTRACTION OF EUGENOL FROM GALANGAL RHIZOME
}

\author{
ADI YUGATAMA*, NUR WAHIDA ARDIYATI, IRA YULIANTI \\ Department of Pharmacy, Faculty of Mathematics and Natural Sciences, Sebelas Maret University, Indonesia. \\ Email: adiyugatama.apt@gmail.com
}

Received: 3 November 2016, Revised and Accepted: 24 January 2017

\section{ABSTRACT}

Objective: The main objective of this study was to determine the optimal ethanol concentration as solvent for extracting eugenol from galangal.

Methods: Galangal rhizome extraction was conducted with kinetic maceration at $50^{\circ} \mathrm{C}$ with various ethanol concentration as solvent $(0 \%$, $30 \%$, $50 \%, 70 \%$, and 96\%). A 1:10 ratio of rhizome and ethanol was applied. The extract was obtained, then its eugenol concentration was analyzed qualitatively and quantitatively by thin-layer chromatography-densitometer with n-hexane:ethyl acetate (4:1) by using mobile phase and silica gel 60 $\mathrm{F}_{254}$ as stationary phase and applying a wavelength of $283 \mathrm{~nm}$.

Results: The result of qualitative analysis showed that extract of $70 \%$ and $96 \%$ ethanol had a spot with Rf value 0.63 , which was equal to the Rf value of standard eugenol. Standard curve equation for the $70 \%$ ethanol extract was $y=89318 x+656.07$ ( $r=0.9993)$ and for the $96 \%$ ethanol extract was $y=8658 x+1743$ ( $r=0.9999)$. The result of the quantitative analysis showed that the $70 \%$ and $96 \%$ ethanol extract contained $4.85 \%$ and $4.79 \%$ eugenol, respectively.

Conclusion: Extraction of galangal rhizome in $70 \%$ and $96 \%$ ethanol was positively containing eugenol. Highest eugenol concentration (4.85\%) was obtained from galangal rhizome extraction in $70 \%$ ethanol.

Keywords: Eugenol, Galangal, Extraction, Densitometer.

(C) 2017 The Authors. Published by Innovare Academic Sciences Pvt Ltd. This is an open access article under the CC BY license (http://creativecommons. org/licenses/by/4. 0/) DOI: http://dx.doi.org/10.22159/ajpcr.2017.v10s2.19474

\section{INTRODUCTION}

One of the medicinal plants that contains essential oil is galangal (Alpinia galanga). Galangal is included into Zingiberaceae familia, rhizome class, that is often used as food seasoning or spices since it has a fragrant aroma and spicy flavor. Galangal also used as traditional medicine. It could treat gastrointestinal disordes, eliminate bloating, infection, and potential for curing cancer because of its antioxidant activity (chemoprevention) [1-3].

Eugenol is one of essential oil contained in galangal. It is beneficial for human health. Eugenol has anti-inflammatory activity in acute lung injury [4]. Eugenol also has antioxidant properties [5,6]. Another study showed that eugenol has anticancer activity $[7,8]$. Eugenol also has antidepressant and anthelminthic activities $[9,10]$. Various benefits of eugenol was a reason to optimize the solvent used to extract eugenol from galangal rhizome, to obtain the highest concentration of eugenol.

\section{METHODS}

Plant

The galangal rhizome was collected in the Mojosongo market and authenticated by Suratman, Department of Biology, Sebelas Maret University.

\section{Preparation of plant extract}

The galangal rhizome was washed, dried at $25^{\circ} \mathrm{C}$, and then powdered. Galangal powder then extracted using 5 series of ethanol concentration $(0 \%, 30 \%, 50 \%, 70 \%$, and $96 \%)$. The ratio of galangal powder and ethanol was 1:10. Simplisia powder and extraction solvent heated on water bath at $50^{\circ} \mathrm{C}$ for $1 \mathrm{hr}$ with stirring. Liquid extract obtained was separated, then thickened with rotary evaporator at $40^{\circ} \mathrm{C}$. Viscous extract obtained was stored in the refrigerator.
Optimization of analysis eugenol

Extract and eugenol standard spotted on a thin-layer chromatography (TLC) plate (silica gel $\mathrm{GF}_{254}$ ) and eluted with various proportion of mobile phase $n$-hexane:ethyl acetate, which were $1: 4 ; 2: 3 ; 3: 2$; and 4:1. Spots were observed at ultraviolet $254 \mathrm{~nm}$ and $366 \mathrm{~nm}$. The separation then watched and calculated Rf value continued by densitometry TLC scanning. Comparison of mobile phase n-hexane:ethyl acetate which optimal was 4:1, which gained good separation and Rf value of eugenol 0.63

Analysis quantitative of eugenol

Eugenol was created into a series of standard curve concentration, i.e., $950,1000,1050,1150,1200$, and $1250 \mathrm{ppm}$, then by $2 \mu \mathrm{l}$ spotted on TLC plate and eluted with mobile phase n-hexane:ethyl acetate (4:1). TLC plate then measured its area under curve and peak height using densitometer TLC scanner at wavelength of $283 \mathrm{~nm}$.

\section{RESULTS}

The TLC result showed that eugenol were found in sample D and E (Figure 1). Densitometer spectra showed that sample D, E, and eugenol standard were having the same profile (Figure 2). The highest eugenol content was found in sample D $(4.85 \pm 0.03)$ (Table 1$)$.

\section{DISCUSSION}

Extraction solvent used was ethanol because eugenol having a good solubility in ethanol [11]. Qualitative identification of eugenol was done by TLC. Advantages of TLC were easy to use, simple techniques, and quick time needed. TLC was a method of chemical mixture separation in a sample based on differences in migration of each component in the mixture to the stationary phase under the influence of mobile phase. Selection of mobile phase is important because it can affect 
the migration of spots during elution progress or may affect the Rf value. Results of the selection of mobile phase showed that mobile phase n-hexane:ethyl acetate (4:1) gave separated eugenol from other compound in the extract with the value of Rf 0.63 . Mobile phase of n-hexane:ethyl acetate (3:2); (2:3); and (1:4) did not show a good spot separation. It was because the mixture of mobile phase too polar, so the solute eluted until the upper limit. That was because the solute did not hold firmly on the stationary phase. The principle of TLC method is "like dissolve like", means that solubility is based on similarity of polarity properties. Eluent used was relatively non-polar because the

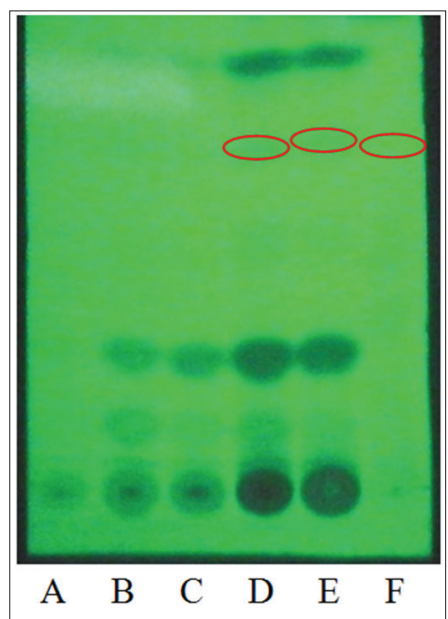

Fig. 1: Qualitative identification of eugenol in ethanol extract of galangal rhizome (A - 10\% ethanol, B - 30\% ethanol, C - 50\% ethanol, D - 70\% ethanol, E - 96\% ethanol, F - eugenol standard) composition of n-hexane was more than ethyl acetate so that can elute eugenol which is relatively non-polar.

Based on TLC result, it can be seen that only sample D (70\% ethanol) and $\mathrm{E}(96 \%$ ethanol) indicating a spot that were parallel to the eugenol standard (Spot F) with Rf value 0.63 for sample D and 0.64 for sample E. Rf value of eugenol standard and sample was similar, with difference value $\leq 0.2$. Similar value of $\mathrm{Rf}$ strengthen the suspicion that galangal rhizome extract in $70 \%$ and $96 \%$ ethanol were containing eugenol. To prove the suspicion, we were conducted further qualitative analysis using TLC scanner. The result showed that there were similarity between spectra profile densitometer of standard eugenol and galangal rhizome extract in $70 \%$ and $96 \%$ ethanol. It could be concluded that samples were positively containing eugenol.

Spectrum result by TLC scanner showed that maximum absorption of eugenol obtained at $\lambda 283 \mathrm{~nm}$, whereas according to other study, maximum $\lambda$ of eugenol was $282 \mathrm{~nm} \mathrm{[12].} \mathrm{Different} \mathrm{wavelength}$ of $\leq 3 \mathrm{~nm}$ was still within the tolerance limit allowed [13]. The linear regression equation obtained from standard curve I was $y=89318 x+656.07$ with a correlation coefficient (r) of 0.9993 and standard curve II was $y=8658 x+1743$ with a correlation coefficient (r) of 0.9999 . The standard curve obtained have been fulfilled the linearity requirement, which is value of correlation coefficient $>0.998$ [14]. The result of eugenol concentration from galangal rhizome extract was $4.85 \%$ by $70 \%$ ethanol extract and $4.79 \%$ by $96 \%$ ethanol extract.

\section{CONCLUSION}

The study showed that extract of galangal rhizome in $70 \%$ and $96 \%$ ethanol contains eugenol. The highest eugenol concentration is an extract of galangal rhizome in $70 \%$ ethanol, which was $4.85 \%$.

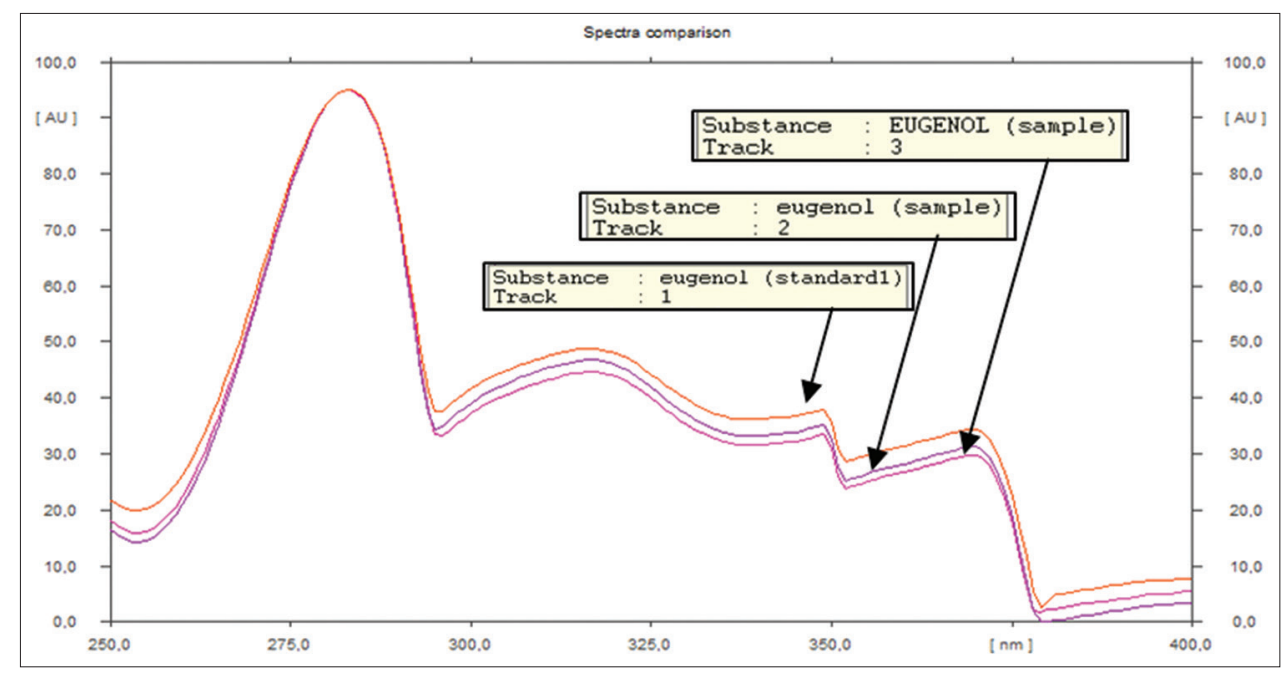

Fig. 2: Spectra profile of eugenol by densitometer

Table 1: Concentration of eugenol in ethanol extract of galangal rhizome

\begin{tabular}{|c|c|c|c|c|c|}
\hline Sample & Spotting replication & AUC & Concentration $(\mu \mathrm{g})$ & Concentration \pm SD $(\%)$ & $\%$ RSD \\
\hline \multirow[t]{3}{*}{ Ethanol 70\% } & 1 & 22514.44 & 2.45 & $4.85 \pm 0.03$ & 1.51 \\
\hline & 2 & 21927.52 & 2.39 & & \\
\hline & 3 & 22487.55 & 2.44 & & \\
\hline \multirow[t]{3}{*}{ Ethanol 96\% } & 1 & 22783.07 & 2.43 & $4.79 \pm 0.05$ & 2.055 \\
\hline & 2 & 21997.00 & 2.34 & & \\
\hline & 3 & 22668.82 & 2.42 & & \\
\hline
\end{tabular}

SD: Standard deviation 


\section{ACKNOWLEDGMENT}

We are thankful to Pharmacy Laboratory and UNS Laboratory Center for the facilities so that research could be done.

\section{REFERENCES}

1. Chan EW, Ng VP, Tan VV, Low YY. Antioxidant and antibacterial properties of Alpinia galanga, Curcuma longa, and Etlingera elatior (Zingiberaceae). Pharmacogn J 2011;3(22):54-61.

2. Köse LP, Gülçin İ, Gören AC, Namiesnik J, Martinez-Ayala AL, Gorinstein S. LC-MS/MS analysis, antioxidant and anticholinergic properties of Galanga (Alpinia officinarum Hance) rhizomes. Ind Crops Prod 2015;74:712-21

3. Matsuda H, Pongpiriyadacha Y, Morikawa T, Ochi M, Yoshikawa M. Gastroprotective effects of phenylpropanoids from the rhizomes of Alpinia galanga in rats: Structural requirements and mode of action. Eur J Pharmacol 2003;471:59-67.

4. Huang X, Liu Y, Lu Y, Ma C. Anti-inflammatory effects of eugenol on lipopolysaccharide-induced inflammatory reaction in acute lung injury via regulating inflammation and redox status. Int Immunopharmacol 2015;26(1):265-71.

5. Nam H, Kim MM. Eugenol with antioxidant activity inhibits MMP-9 related to metastasis in human fibrosarcoma cells. Food Chem Toxicol 2013;55:106-12.
6. Das S, Hakim A, Mittal A. Study of the antihyperlipidemic, antioxidative and antiatherogenic activity of Aegle marmelos Linn. In rabbit receiving high fat diet. Asian J Pharm Clin Res 2012;5(4):69-72.

7. Anita Y, Sundowo A, Dewi NL, Filailla E, Mulyani H, Risdian C, et al. Biotransformation of eugenol to dehydroeugenol catalyzed by brassica Juncea peroxidase and its cytotoxicity activities. Procedia Chem Int Symp Appl Chem 2015;16:265-71.

8. Manikandan P, Murugan RS, Priyadarsini RV, Vinothini G, Nagini S. Eugenol induces apoptosis and inhibits invasion and angiogenesis in a rat model of gastric carcinogenesis induced by MNNG. Life Sci 2010;86(25-26):936-41.

9. Irie Y, Itokazu N, Anjiki N, Ishige A, Watanabe K, Keung WM. Eugenol exhibits antidepressant-like activity in mice and induces expression of metallothionein-III in the hippocampus. Brain Res 2004;1011(2):243-6.

10. Boijink CD, Miranda WS, Chagas EC, Dairiki JK, Inoue LA. Anthelmintic activity of eugenol in tambaquis with monogenean gill infection. Aquaculture 2015;438:138-40.

11. Budavari S. The Merc Index. USA: Merck \& Co Inc.; 1996.

12. Pramod K, Ansari SH, Ali J. Development and validation of uv spectrophotometric method for the quantitative estimation of eugenol. Asian J Pharm Anal 2013;3(2):58-61

13. Depkes RI. Farmakope Indonesia. $4^{\text {th }}$ ed. Jakarta: Departemen Kesehatan RI; 1995.

14. Chan CC, Lee YC, Lam H, Zhang XM. Analytical Method Validation and Instrument Performance Verification. New Jersey: Wiley; 2004. 